\title{
The United Nations Security Council Resolution 1325 (UNSCR 1325) and The Challenges of Women Participation in Peace Building and Conflict Resolution in Nigeria: Critical Analysis
}

\author{
E. Ekpe Dickson \\ Department of Political Science \\ University of Calabar \\ Calabar - Nigeria.
}

\begin{abstract}
In 31 October, 2000, the United Nations Security Council adopted and signed SC Resolution 1325 on Women Peace and Security. Resolution 1325 recognizes that civilian, particularly women and children are the worst affected by conflict. Resolution 1325 call for women participation in conflict prevention and resolution initiative, the integration of gender perspective in peace building, peace keeping mission and the protection of women in regions of conflict. The resolution reaffirms the important role of women in the prevention and resolution of conflicts, peace negotiations, peacebuilding, peace keeping, humanitarian response and in post-conflict reconstruction; stressing the importance of equal participation in peace and security. In Africa, women participation in policy making, peace building and conflict resolution is still faced with setbacks despite the passing of the SCR 1325 two decades ago. Findings from this study has shown that, women have been subjected to domination by men as a result of persisting cultural stereotypes, abuse of religious and traditional practices, patriarchal societal structures in which economic, political and social power are dominated by men while women played the role of followers of male decision-makers. The study identifies such challenges for a change or reforms them. The paper reviewed many of the extant studies on the role and potentials of women in peace building and conflict resolution. Analyzing those challenges inhibiting the participation of women in peace process. The paper adopted the qualitative approach whereby data collected from secondary sources were reviewed, explained and analyzed within the purview of the study. The paper conclude, the views that bringing women into the peace process, as participation of women makes it sustainable and reduces possibility of inadequate outcome or failure of the entire process, may be an illusion. Unless the women are economically and politically empowered, as one of the outstanding equality of peacemakers or negotiators is the amount of political and economic influence they possessed. Only elite centric gender blind composition of negotiation and peace process team cannot ensure sustainable peace process as there could be no peace with one side so disadvantaged.
\end{abstract}

Keywords: Conflict Resolution, Participation, Peace Building, UNSCR 1325 \& Women

\section{INTRODUCTION}

The United Nations Security Council Resolution 1325 (UNSCR 1325) on women peace and security, which was adopted by the security council on $31^{\text {st }}$ October, 2000 presents a comprehensive political framework within which the protection of women and their role in peace processes can be addressed. The council demand a whollistic assessment of the impact of armed conflict on women and girls, the role they play in peace building and the gender role in the peace processes and conflict resolution. 
The UN Resolution 1325 provide the first international legal and political framework recognizing the effect of armed conflict on women as well as the central role of women in peace building. It acknowledges the importance of the participation of women and the inclusion of gender perspective in peace negotiation, humanitarian planning, peace keeping operation, post-conflict peace building and governance. UN Resolution 1325 address not only the excesses effect of war on women, but also the pivotal role women should play in conflict management, conflict resolution and sustainable peace. However, the implementation of SCR 1325 and following development indicators show little evidence of success in conflict ridden countries like Nigeria. Though the resolution rely on many assumptions such as the potentials for women's participation to have a transformational effect on peace and security. There is continuous infinitesimal representation of women in formal peace processes, although they contribute in many informal ways to conflict resolution. In recent peace negotiations for which such information is available, women have represented fewer than eight percent of participants and fewer than three percent of signatories and no woman has ever been appointed chief or lead mediator in UN sponsored peace talk. Such exclusion invariably lead to a failure to adequately address women's concerns such as sexual and gender-based violence, women rights and post-conflict accountability (FMWASD, 2017:8).

Nigeria as a nation faces conflict challenges such as economic crisis, a resurgence of militancy in the Niger Delta, Pro-Biafra Nationalist, conflict in the Middle Belt over use of land. The conflict in the North East caused by Boko Haram has continued to unleash unprecedented havoc in that region resulting in massive loss of lives, property and livelihoods. Nigerian women are at the receiving end of these conflicts that have been ravaging the country. Women have been seriously abused, assaulted; brutally abducted; enslaved; forced into marriage; brain-watched and used as suicide bombers by their captors and have also been forced to pick up arms and become terrorists and several of them are widows and flee from their homes. In Nigeria, a national strategic framework and plan of action for the implementation of UNResolution 1325 is anchored on the following:

$>$ Participation: Increased political empowerment for women and engagement at all levels of decision making.

$>$ Justice, Protection and Peace: A more effective and credible justice and security environment for women during and after conflict.

$>$ Economic Resources and Support: Allocation of greater and more sustainable financial resources to support women recovery processes (FMWASD, 2017).

It is expected to develop and activate strategies that would strengthen women's organizations to participate in peace processes as well as ensure that gender perspectives are included in peace keeping operation. It is clear that women's participation in peace and conflict resolution is seriously limited and inhibited by quite a number of factors that range from societal, cultural, psychological, economic and political factor (Damilola, 2006). One may attribute the main causes of weak action to non-participation of women in decision and implementation processes to the above limiting factors. The paper analyse the challenges that could inhibit the success of implementing the UNSCR 1325 in Nigeria. And also a summary of many of the enlightened literature on the role/potentials of women in peace building and conflict resolution and conclude.

\section{CONCEPTUAL EXPLANATION}

UNSCR 1325: The United Nation security Council Resolution 1325 (UN Resolution 1325) on women peace and security was adopted by the security council on 31 October, 2000 . It present a comprehensive political framework within which the protection of women and girls from sexual and gender-based violence in armed conflict and their role in peace process can be 
addressed. It acknowledged the disproportionate and unique impact of armed conflict on women and girls. It calls for the adoption of a gender perspective to consider the special needs of women and girls during conflict, repatriation and settlement, rehabilitation, reintegration and post-conflict construction. Resolution 1325 was the first formal and legal document from the Security Council that required parties in a conflict to prevent violations of women's rights, calls for increased participation of women at all levels of decision making, in national, regional, and international institutions; in mechanisms for the prevention, management and resolutions of conflicts in peace negotiations; in peace operations, as soldiers, police and civilians, and as special representatives of the UN Secretary-General(UNSCR 1325 report). The key components and recommendations of the Resolutions are:

> Preventing sexual and gender-based violence in armed conflict: Resolution 1325 calls upon all parties in conflict to take special measures to protect women and girls from violence in armed conflict, particularly sexual and gender-based violence. It also calls for states to ending impunity for crimes against humanity, particularly sexual violence and prosecute offenders;

$>$ Peace negotiation: The resolution calls for including a gender perspective in peace negotiations and increasing women's participation in peace negotiation, with particular attention to supporting local women peace initiatives;

$>$ Protection of women and girls in refugee setting: The resolution calls upon parties to conflict to consider the special needs of women and girls in designing and administering refugee camps.

$>$ Disarmament, demobilization and reintegration (DDR): It also calls for considering gender in DDR, particularly the different needs of male and female ex-combatants.

$>$ Women's participation in politics: The resolution calls upon member states to increase women participation at all levels of decision-making in national regional and international institutions.

$>$ Provide training for the UN and member states on the protection, rights and needs of women's gender sensitivity and the importance of involving women in peacekeeping and peace-building measures.

$>$ Gender balancing in the UN: Increase women's representation as special representatives and envoys and in field operations, particularly among military observers, police, and human rights and humanitarian personnel (UNSCR 1325, 2000).

\section{Peace:}

Rummel (1981) regards peace as the absence of dissension, violence or war; a state of concord, harmony and tranquility. Galtunng (1996) added that, it is a state of absence of hostility, disturbance or agitation. To Phil-Eze (2009) peace reigns where there is a state of justice or goodness and a balance or equilibrium of powers or where natural respect for another's right, ideas, views or person is observed. For us, peace is the state of social, psychological, physical and spiritual wellbeing on an individual; the state of harmonious relationship, absence of violence, war, freedom from dispute, freedom from mental stress or anxiety between individual, groups, states or nations. However, peace is mostly perceived by many as absence of war. Their perception is passive and simplistic having a serious oversight in the fact that it does not put into account the residual feelings of mistrust and suspicion that the victor and vanquish of war harbor towards each other. Furthermore, Woolman (1985) argued that another way of thinking about peace is to have it defined in negative and positive terms. Peace as a mere absence of war, he refers to as negative peace. Negative peace is defined as a state requiring a set of social structures that provide security and protection from acts of direct physical violence committed by individuals, groups or nations. These policies are thought to be insufficient to assure lasting conditions of peace. Negative peace efforts may instead lead to future violence of greater magnitude. Positive peace lays emphasis on a pattern of cooperation 
and integrations between major human groups; it is about social organization of diverse people whom willingly choose to cooperate for the benefit of all human kind. There are no winners nor are losers, all winners.

\section{Conflict Resolution:}

Conflict resolution in theoretical terms is different from the general category of conflict management which includes efforts and interventions to limit, contain or regulate conflict. John Burton (1990) argued that protracted socio-political conflicts have resisted the efforts of the international community to control them; conflict resolution emerged as an alternative means of resolving rather than merely pacific settlement of disputes. Miller (2003:8) stated that; "it is a variety of approaches aimed at terminating conflict through constructive solving of problems, distinct from management or information of conflict". From the point of view of needs, a conflict is resolved when the basic needs of parties have been met with necessary satisfiers and their fears have been allayed. It is a principle and process in concert with communication channels open to parties in a conflict which involves the reduction, elimination or termination of all forms and types of conflicts.

\section{Peace-building:}

It is the creation and nurturing of constructive relationships across ethnic, religion, class and racial boundaries. Peace builders seek to resolve social inequalities and transform structural condition that generates deadly conflicts. The aim of peace building is to end armed violence and establish human rights, democracy, protection and fostering reconciliation after post atrocities. Moreso, it is a term describing interventions that are designed to prevent the start or resumption of violent conflict. Strategic peace building connects peace and groups on ground (that is the community and religious groups, grassroot organizations, etc.) with policy makers and power brokers (governments, the UN, corporations, bankers, etc.) It aim not only to resolve conflict but to build societies, institutions, policies and relationships that are better able to sustain peace and justice, strategic issues such as economic prosperity and environmental sustainability as well as violence and recognizes that peace making is a longterm vocation that requires the building of cross-group networks and alliances that will survive intermittent conflicts and create a platform for sustainable human development and security. The vitality of women in peace building includes:

$>$ Women are half of every community, task of peace building are so great, women and men must be partners in the process of peace building.

$>$ They are the central caretakers of families.

$>$ Women have the capacity for both violence and peace, use of gift in building peace.

$>$ Because women are excluded in public decision making.

$>$ Because women have already proven themselves to be successful peace builders.

$>$ Because the United Nations Security Council Resolution 1325 created a mandate to involve women in peace building.

$>$ Because sexism, racism, classism, ethnic and religious discrimination originated from the same set of beliefs that some people are inherently better than others, women engaged in peace building often challenge these sexist beliefs along with other structures that discriminate against women (Lisa Scirch \& Manjrika Sewak, 20005).

\section{Conflict:}

Conflict has many definitions. As far as human society exists, conflict will persist because of unjust wealth and unjust poverty. Francis (2003) defines it as the pursuit of incompatible interests and goals by different groups; for Oquaye (1995), it is a sequence of interactions between groups in society; between groups and government, and between individuals; Coser (1995) sees it as the struggle over values, claims to status, power and scarce resources in 
which the aims of the opposing party are not only to gain the desired values but also to neutralize, injure or eliminate rivals; Zartman (1997) sees it as a normal state of human interaction; as an inevitable aspect of human interaction, an unavoidable concomitant of choices and decisions. It is a natural announcement of an impending reclassification of a society with changed characteristics and goals with new circumstances of survival and continuity and this entails struggle, competition, rivalry for objects to which individuals and groups attach values, which could be material or non-material. For Miller and King (2005), define conflict as;

A confrontation between one or more parties aspiring towards incompatible or competitive means or ends (which) may be either manifest, recognizable through actions or behaviours, or latent, in which case it remains dormant for some time, as incompatibilities are unarticulated or are built into systems or such institutional arrangements as governments, corporations, or even civil society.

Thus conflict arise whenever there is the pursuit of divergent interests, goals and aspirations by individuals, or groups in defined social and physical environment. Moreso, issues such as poverty, struggle for scarce resources, lacks of infrastructures and violations of human rights are identified as the root causes of conflict in society. It is not surprising that conflict occur at all levels of human interactions, i.e. within a family and between families, a community and within communities, states and between states. Today attention has also focused on global conflict where non-state groups combat international and regional organizations.

\section{THEORETICAL FRAMEWORK}

The paper adopt an eclectic approach by which selected theories of gender roles in the society will be adopted to explain the differential access of man and women on resources and political power. Theories of gender roles in society are basically rooted in the patriarchal and matriarch theories which many political theorists explore to demonstrate the legitimacy of gender role and power relations in the society.

The Patriarchal Theory (Greatest Supporter Sir Henry Maine 1822-88), Maine cited the patriarch of the Old Testament, the Brotherhoods of Athens, the patria-protesters in Rome and the family system in India as evidence in favour of his theory (women subordination to men).

The theory explains that the state originated from patriarchal family or the family in which the pater or father was the head. His control and authority was complete in all respects over all its members. It described the structures that perpetrate gender inequality in the society which brings about gender differentiation in power relations between men and women. A social system in which men hold primarily power and predominate in roles of political leadership, moral authority, social privilege and control of property. Some patriarchal societies are also patrilineal, meaning that property and title are inherited by the male lineage. Patriarchy is associated with a set of ideas, a patriarchal ideology that acts to explain and justify this dominance and attributes is to inherent natural difference between men and women. Patriachy has manifested itself in the social, legal, political, religious and economic organization of a range of different cultures. Historically the term was used to refer to automatic rule by the male head of a family. And in the $20^{\text {th }}$ century, patriarch has been used to refer to social systems in which power is primarily held by adult men. The context was developed to explain male dominance as a social rather than biological phenomenon. Aristotle also conceded to this notion in his political theory of state in his analysis of human nature when he referred man as a political animal. He portrayed women as morally, intellectually and physically inferior to men; such women as the property of men; claimed that women's role in society was to reproduce and to serve men in the house hold and saw male domination of women as natural and virtuous. From the Marxist perspective, Fredrick Engels, assigns the 
origin of patriarchy to the emergence of property which traditionally been controlled by men. In this view men diverted production and sought to control women in order to ensure the passing of family property to their owner (male) offspring, while women were limited to household labor and producing children. However, this argument was disputed by Lerner (1965) arguing that patriarchy emerged before the development of class based society and the concept of private property. And that the patriarchal belief system passed down generation to generation, people have been conditioned to belief that men are superior to women. This explain why some parts of Nigeria, most especially in the Northern part of the country, they religiously believe that participating in politics, conflict resolution and negotiations in the society is the preserve for men which has become a gender issue.

These symbols are benchmarks which children learn about when they grow up and the cycle of patriarchy continues. Although many $16^{\text {th }}$ and $17^{\text {th }}$ century theorists agreed with Aristotle's view concerning the place of women in the society; in the latter half of the $18^{\text {th }}$ century, clerical sentiments of patriarchy were meeting challenges from intellectual authorities. Dheret (2011) denies inheritance of paternal authority stating that mother have rights and authority equal to those of fathers for the obligations imposed on children originated equally from the mother and father as both are equally responsible for bringing them into the world. Thus the positive laws of God that relate to the obedience of children join the father and the mother without any differentiation; both possess a kind of ascendency and jurisdiction over their children. In modern times the concept of patriarchy is asserted to manifest itself in institutionalized control rather than simply being about individual sexism. Therefore in a patriarchal societies group of individuals have been tagged and groomed to be the decision makers for another group considered inferior weak and subordinate.

The invocation of cultural beliefs, values and the maintenance of the status quo kept the decision making group at the top. Unfortunately in many societies women are considered weak while men are the decision-makers hence patriarchal system a factor in the under representation or not inclusion of women in peace negotiation, conflict resolution and decision making process. Nigeria society is permeated by patriarchy whereby women are expected to conform to and confined themselves to male dominance and female subservience, women are seen to belong to the home, being incapable of making sound decisions and it is unbecoming of women to expose themselves in public for political activities such as campaign, rallies, men often find it incredible and impracticable to see them participating in politics or conflict resolution committees (Dayo, 2006:205). The theory is regarded by many scholars as a social construct or a framework which gage the basis by which inequality in political authority was fabricated upon.

Against this background, Feminist theory came out as a relatively recent and highly provocative theory which advocates the emancipation of women for equal rights. It is a critique as well as a theory committed to women emancipation challenging the public and private divides in policies which had historically denied women access to political space (Sott, 1986). The theory focuses on gender roles in society within the state, institutions and policies. It questions liberalistic thought which claim indifferences to gender and taken its time to open up to such gender concerns (discrimination in policies, economic, social, legal, violence against women rape etc.). It shines on social problems, trends and issues that are otherwise over looked or misidentified by the historical dominant male perspective within social theory. Key area of focus within feminist theory includes discrimination and exclusion on the basis of sex and gender objectification, structures, economic, inequality, power and oppression, gender roles and stereotype among others (Chodoraw, 1990). 
However, the notion that feminist theory focuses exclusively on girls and women, that it has inherent goal of promoting the superiority of women over men is false. Rather it examined the masculinity war and national security that state national policies are often legitimated in favor of masculine characteristics. They help us understand why women have been so underrepresented in powerful position in the international policies, militaries, peace building and conflict resolution. The most important goal for the feminist theory is to explain women subordination which exists to varying degrees in all societies and to seek ways to end it and disagreed why women are subordinate and how to overcome it. Moreover there are versions of feminist theory which give us different reasons for women subordination. The liberal, socialist post-colonial, post-colonial modern and Marxists. The liberal feminist believe that removing legal obstacle can overcome women subordination. All other approaches see deeply rooted structures of patriarchy. Marxist and socialist feminists look for explanations for women subordination in the labour market that offers greater rewards and prestige for paid work in the public sphere than for unpaid work in the house hold. Women do most of the unpaid work even when they work for wages thus imposing what feminist call a double burden (Sylvester, 1994). The above theories illustrate the various differential accesses of men and women to societal resources and responsibilities. It could be taken as a scaffold within which this study bases its analysis.

\section{CHALLENGES OF WOMEN PARTICIPATION IN PEACE-BUILDING AND CONFLICT RESOLUTION}

Past historical experience has shown that women have been subjected to domination by men, as a result of persisting cultural stereotype, abuse of religious and traditional practices, patriarchal societal structures in which economic, political and social power are dominated by men and the role women have historically played as the followers of male decision makers.

\section{Political challenge:}

The absence or under-representation of women in the very process of decision making and implementation of policies is a consequence of the unequal status between men and women in terms of power relations having profound implications for how they participate and are located within the power structure of the society. Politics and political arrangement in Nigeria has weaken female legitimacy resulting in women's political powerlessness. Despite efforts made by them locally and internationally to improve the situation of women in politics, little impact has been recorded as women are still excluded from the mainstream because they are politically powerless. Their influence in decision making is equally abysmal and not commensurate with their number. Moreso, women's perception of politics does not give them the opportunity to participate in any peace process. Their belief that men possess the superiority, strength, competitiveness, self-reliant and are prepared to struggle in political issues. Whereas, they are considered too passive to peace process. The societal norms and values through socialization has defined different gender roles according to biological differences and this is not to their advantage in participating in conflict resolution. Nigerian women are considered a weaker sex and their participation at all levels of governance discouraged. In some communities, most especially in the north (religious belief) considered it a taboo for women, in spite of several international conventions and treaties (e.g. UNSCR 1325, etc.) that encouraged women participation in politics, peace process in which Nigeria is a signatory to such conventions and treaties. The unequal power relations between men and women undermine their participation in the peace processes.

\section{Economic challenge:}

Gelpi, et al., (1986) make a strong case of the importance of alleviation of poverty, as an important step towards emancipation of women politically and economically. Lack of funds, 
resources, poverty and unemployment, violence against women, economic discrimination put them at a disadvantaged position to influence meaningful political decisions in the state. High percentage of women employment is restricted to low income-generating activities concentrated within the lower levels of the unregulated informal sectors which are not adequately represented in the National Accounting System (NAS). Men are given productive gender roles enabling them to possess more purchasing power and influence over their female counterparts as one of the outstanding quality of peace-makers or negotiators is the amount of political and economic influences they possessed. In Nigeria, only very few are affluent possess the economic power to serve in peace process committees. Women were not considered fit and proper to own and engage in any meaningful investment that will allow them grow financially independent that will enable them take active part in decision making and implementation as to taking part in peace process committee even as chief negotiators. This cannot allow the women to match naira for naira in Nigeria monetized political environment.

\section{Socio-cultural challenge:}

Strict adherence to cultural practices that discriminate against women (especially in the north), may bring about resistance to the proposed change and hinder a successful implementation of the UN Resolution 1325. Societal values norms and religion assumes, political activities are masculine and therefore prefer male participation in peace process than female. Societal reality is deeply rooted in the cultural beliefs and values of societies in the world; some areas of activities are always seen as exclusively or predominantly male and therefore overwhelmingly and morally important (Rosaldo and Lamphere, 1974:20-22). And so women have been excluded in the area of conflict resolution or peace process as reserve for men. These societal beliefs as well as ethnic religious doctrines and norms have turned into self-fulfilling prophesies. Again, Nigeria is a highly patriarchal society, where men dominate all spheres of women's lives. Women are in a subordinate position (particularly at the community and household levels). Patriarchy is exacerbated in the culture of male supremacy. The patriarchal cultural norm remains obscured and protected within traditional institutional structures held in abeyance and almost in sacredness. It is common to use customary practices to discriminate against women because customary laws and prctices constitute a major source of law and enjoy wide acceptance. It is binding and enforceable. In some cultures, women are not allowed to inherit their parents, participate in community development, family matters, and in the peace process. Agbalajobi (2009:79) argued that the "overall impact of gender bias, cultural norms and practices has entrenched a feeling of inferiority in women and place them at a disadvantaged vis-à-vis their male counterpart in the socio-political scene even in urban centers". These norms and stereotype role make women accept they are weaker sexes regarding participation in peace processes exceptional for men masculine ability.

\section{Competitive tendency of women:}

Another challenge lies within the women themselves. Nigerian elites women are too much divided (politically, socially and psychologically). Most of them are heavily guided by the political agenda at the cost of common interests. For instance, during the primaries of People's Democratic Party (PDP) to select their presidential candidate for the 2011 general elections. Mrs. Sarah Jubril, the only female candidate got only one vote out of about $1 / 4$ female delegates (Ekpe, D.E, et. al, 2014) It clearly showed that women could not work together for the common course and often competes each other in the area where their collaboration could benefit more to address the cause on which they are working. The main causes of non-cooperation among women can be categorized as follows:

$>$ Psychological: Ego driven, I am special than others (language, social class, international linkages and networks, etc.)

$>$ Political: Political pressure or political ambition. 
$>$ Social: Personality build on feudal social structure (from rich family, from higher social class, higher education, education from abroad, etc.)

$>$ Special relations with international power, better access to information and resources (cited in Upreti, 2008:10).

However, as a weaker sex, they should be encouraged and given opportunity to participate in any peace process as women and children are worst affected by conflict and a threat to peace and security.

\section{Constitutional challenge:}

Despite a general commitment the principle of non-discrimination enshrined in section (2) of the 1999 constitution of the Federal Republic of Nigeria fall short of the desired result of given male and female equal opportunities to advance socially, politically, physically, educationally and economically. The problem is the practical effects and its linkage to fundamental ideas of fairness and justice. However, the constitution was not explicit in ensuring equal representation on sexual based. Like constitution of some African countries, like South Africa, Uganda, the Nigerian Constitution take no cognizance of the disadvantaged position of women and has no provision for gender equality. And there is nothing in the constitution that seems to address the disparities that exist along gender lines in Nigeria. The Nation's legal system is based on a tripartite system of laws (Statutory, Customary and the Sharia) which is sometimes contradictory. Thus has made it difficult to fulfill one of the basic stipulations of Nigerian constitutions which required that all citizens be treated as equal under the law (Ekpe, D.E.et al 2016: 141).

\section{THE ROLE/POTENTIALS OF WOMEN IN PEACE-BUILDING AND CONFLICT RESOLUTION}

Upreti, B.R.(2008:3) argued, experiences around the world have demonstrated that women can play important roles in all elements of peace process such as implementation of UNSCR 1325; crisis management, peace talks and agreements, post conflict transitional management, transitional security and transitional justices, post conflict construction and rehabilitation.

Thus:

"Women can make peace agreements and post conflict efforts more viable, effort and practical by engaging in a wide variety of actions, including but not limited to participating in peace talk; rehabilitating children associated with armed groups; convening people across conflict lines to discuss common concerns such as access to clean water, advocating budget priorities that emphasized social services rather than military expenditure". (ICG, 2006:1)

History has proved that women has demonstrated initiatives to promote peace International Congress of Women (popularly known as ICW) where more than thousands of people gathered in Hague in April, 1915 from the European countries entangled in First World War with the specific aim of ending the bloody war, they vehemently demanded to end the war and universal disarmament and more importantly they demanded to create a non-partisan international agency to mediate inter-state conflict (Rehn and Sirleaf, 2002).

Collier (1974) argues that from time immemorial women have always been deeply involved in processes of conflict resolution; the struggle for equal rights was championed essentially by women and is indicative of the peace seeking struggle by women as there could be no peace with one side so disadvantaged. Experiences around the world have demonstrated that women can play important roles in all elements of peace process such as implementation of UNSCR 1325, crisis management, negotiation and conflict management; peace talks and agreement; 
post conflict transitional management; transitional security and transitional justices, post conflict reconstruction and rehabilitation (Upreti, 2008).

Agustiana and Pakpahan (2004), in their assessment on women role in peace building in Central Sulawesi and North Malhku demonstrate that women are not only conflict victims or combatants but also peace builders, decision makers and peace leaders. They further argued that several initiatives of women have contributed to achieve peace; the work of women in Black (a Serbian Women Peace group who organized peace loving women and came to peaceful street protest, they silently stood in front of government offices with play cards to denounce violence and calling for peace), despite the coercive response of the government, and they became successful to make government listen to their voices. The AVEGA (an Association of Rwandan Widows) not only provided psychological support to the conflict victims but also raised constant voices to address the detrimental impacts created by the genocide to society (Upreti, 2008).

In 2006, International Crisis Group conducted comparative studies on some African conflict ridden nations such as Uganda on women initiation on peace promotion indicated that women played crucial role if they are given the formal responsibility in promoting reconciliation and integration. Women can greatly contribute in addressing the sufferings, pains and tragedies of the conflict victims, developing their confidence, bringing communities together. Developing sense of belongingness and normalization of daily life of people requires feelings of security and constant efforts for long time. Hence, mobilization of capacity and commitment of women in facilitating community normalization process is utmost essential (Upreti, 2008:11).

In the same vein, Randall (1987), cited several studies relating to the movement against nuclear proliferation and the manufacture and use of the atomic bombs, many of the participants were women. Also the Greenham protest camp where 30,000 women gathered to protest the installation of cruise missiles in Britain and in South Africa women were among the leading protesters against the apartheid system with many of them facing stiff penalties including even death (Bernstein, 1986). As Lihamba (2003) argued, conflict need not only be big ones where guns face each other but even individual family, clan, village etc. could be source of permanent instability, negating the concept of peaceful co-existence as humans indeed have to live with one another; it is here that women undoubtedly play a significant role, as they are made most responsible for bringing up all human kind (men and women) they virtually determine the kinds of human we are going to be. The 1992 UNFPA report stated that:

"Women chiefly determine the quality of children both male and female... women's education and awareness and their degree of control over family resources determines children's nutritional, mental and physical development. Through these it affects their success and productivity in later life".

Agbajobi (2010) contended that there are obvious reasons why women are important to the peace building process. "Women constitute half of every community and the difficult task of peace building must be done by men and women in partnership. Women are also the central caretakers of families and everyone is affected when they are excluded from peace building; they are advocates for peace, as peace keepers, relief workers and mediators; played prominent role in the horn of Africa such as Sudan and Burundi where they have contributed as observers".

Traditionally, Africa is also known for the involvement of women in traditional mediation in resolving conflicts, most especially in a study conducted by Ngongo, (2003). UNESCO (2003) documented women's role in peace-building in Africa particularly focusing to cases on 
traditional conflict resolution practices. Mirian \& Chinwe (2006) in their study argued that in view of the innate qualities of women and their position in society women can, and must actively involve in conflict prevention and resolution, peace processes as peace envoys and delegations. Women's role in reconciliation is crucial. Reconciliation is being a process of searching for justice, healing and forgiveness, pattern of cooperation and coexistence, women could play important role in these issues by helping conflict victims to address their needs, fears and aspirations and building the broken relationships. Therefore, in any peace process, participation of women makes it sustainable and reduces possibility of inadequate outcomes or failure of the entire process.

\section{CONCLUSION}

The role played by women in peace building and conflict resolution at home and in war times cannot be overemphasized. Women constitute 50 percent of most societies. They have a crucial role to play in peace and conflict situation of any nation. So far, most countries are yet to properly internalize and for this response is the masculine mind set, a true reflection of feudal, patriarchic society. Women themselves have also indirectly or directly contributed to this mind set.

However, it is inappropriate to argue that women role alone brings peace and stability in the country. Meaningful participation of women in peace processes can definitely contribute to achieve meaningful peace, as different studies of other countries have shown, women greatly contributed to peace building, peace operation, reconstruction, rehabilitation, resettlement, repatriation, reintegration and reconciliation (6Rs). Peace building and conflict resolution need the involvement of women during violent conflicts and war as they are forced to assume new roles as head of families, providers, combatants and freedom fighters. This could only be meaningful if women are economically and politically empowered, as one of the outstanding equality of peace-makers or negotiators is the amount of political and economic influence they possessed.

\section{References}

Augustiana, T. and Pakpahan, M. (2004). Women and peace building: Central Sulawesi and Morth Maluku Jakarta: UNDP and National Planning and Development Board (BAPPENAS).

Berstein, H. (1986). For their triumphs and for their tears: Women in Apartheid South Africa. International Defence and Aid Funds.

Bloomfield, D. and Haque (2003). Reconciliation after violence conflict: A handbook Stockholm. International IDEA.

Burton, J. (1990). Conflict: Resolution and Prevention, Vol. 1, London: Macmillan.

Collier, J. F. (1974). “Women in Politics”, Michelle Zimbalist, Rosaldo and Lovise Lamphere. Standard University Press.

Coser, L. (1995). The functions of social conflict. Glencoe: Free Press.

David, F. (2006:21). Peace and conflict studies: An African overview of basic concepts in Best, S. G. (ed.). Introduction to Peace and Conflict Studies in West Africa: A reader. Ibadan: Spectrum Books Limited.

Dayo, O. K. (2006:205). Gender Peace and Conflict in Africa. In Shedrack (2006). Introduction to Peace and Conflict Studies in West Africa. Ibadan: Spectrum Books Limited. Pp. 205-233.

Dheret, C. (2011). How to reduce socio-economic inequality in Europe, European Policy Centre.

Ekpe, D.E, Eja, A.E. and John, E.I.(2014), Women, gender equality in Nigeria: a critical analysis of socio-economic and political (gender issues) J.Res. Peace Gender. Dev. 4(1):15-20

Ekpe D.E. et.al(2016); Strategies for Achieving National Gender Policy in Nigeria: A Critical Analysis. Advances in social sciences research journal, 3 (6). 137-144. 
Federal Ministry of Women Affairs and Social Development (2017). National Action Plan for the implementation of UNSCR 1325 and related Resolution in Nigeria.

Fukuyama, F. (1992). The end of history and the last man. London: Pengiun Books.

Galtung, J. (1996). Peace by peaceful means: Peace and conflict development and civilization. Published by International Peace Research Institute London.

Gelpi, B. (ed.) (1986). Women and poverty. Chicago and London: University of Chicago Press.

ICG (2006). Beyond victimhood: Women's Peace Building in Sudan, Congo, Brussels and Uganda, Africa, Report No. 112 (26 June, 2006). Nairobi International Crisis Group.

Lerner, D. (1915). Causes and effect. New York: Free Press.

Lihamba, A. (2003). Women peace building and conflict resolution skills, Morogoro Region, Tanzania in UNESCO Women and peace in Africa (pp. 111-131). Paris UNESCO Workshop.

Lisaschirch and Manjrika Sewalk ((2005). The role of women and peace building in a paper written for the Global Partnership for the prevention of Armed Conflict.

Miller, C. E. \& King, M. E. (2005). A glossary of terms and concepts in peace and conflict studies, $2^{\text {nd }}$ edition. Geneva: University for Peace.

Ngongo, M. (2003). The traditional mediation of conflicts by women in Cameroon in UNESCO Workshop.

Nwoye, M. A. (2005). Role of women in peace building and conflict resolution in Africa Traditional Societies: Selective Review. Retrieved 01/02/2018.

Oquaye, M. (1995). Democracy and conflict resolution in Ghana. Accra: Gold Type Publication Limited.

Otite, O. (1999). Aspects of conflicts on Theory and Practice in Nigeria. In Otite and Albert (Eds.) Community conflicts in Nigeria: Management, Resolution and Transformation. Ibadan: Spectrum Books.

Phil-Eze (2009). The environment, peace and conflict in Nigeria. In Ikejiani - Clerk (ed.) Peace studies and conflict resolution in Nigeria: A reader. Ibadan: Spectrum Books.

Rehn, E. and Sirleaf, E. J. (2002). Women, War Peace (Independent Experts Assessment on the impact of Armed Conflict on Women and Women Role in Peace Building Progress of the World's Women). New York: UN Development Fund for Women (UNIFEM)

Rondoll, v. (1991). Women and Politics: an International Perspective. Chicago: The University of Chicago Press.

Rummel, R. J. (1981). Understanding conflict and war. Vol. 5, The Just Peace, Beverly Hills, CA, Sage Publications

Scott, J. (1986). "Gender: A useful category of historical analysis, American Historical Review” 91 (5).

Sylvester, C. (1994). Feminist Theory and International Relations in a Postmodern Era. New York: Cambridge University Press.

UNESCO (2003). Women and Peace in Africa: Case studies on traditional, conflict resolutions practices. Paris: UNESCO Workshop.

United Nations Security Council Resolution 1325 (2000, document).

Upreti, B. R. (2008). Women's role in Napal's peace Process, with special reference to inclusion in peace structure: A paper presented at the National Seminar on Women in Constitution by Women for peace and justice.

Kathmandu. (18-19 August, 2008).

Upreti, B. R. and Kama, V. K. (2007). Reconciliation and social political reintegration in Napal: A Background paper prepared for National Human Development Report.

Zartman, W. I. (2000). "Conflict management: The long and short of it”. SAIS Review, Vol. 20, No. 1

Zartman, W. I. (ed.) (1997). Governance as conflict management: Politics and Violence in West Africa. Washington DC: Brooklines Institution Press.

United Nations Population Fund (1992 Report). 